\title{
APLIKASI KELAS IBU HAMIL SEBAGAI UPAYA REKRONSTRUKSI BUDAYA "TARAK" (TIDAK MAKAN MAKANAN TELUR, AYAM, DAGING DAN IKAN) PADA IBU NIFAS DI KABUPATEN BLITAR (Application Mother Class Of Pregnant Women For Culture Rekronstruction "Post Partum Continence" ( Do Not Eat Eggs, Chicken, Meat And Fish ) In The District Blitar)
}

\author{
Zaenal Fanani, Bisepta Prayogi \\ STIKes Patria Husada Blitar \\ email:bisepta_iceman@yahoo.co.id
}

\begin{abstract}
Indonesian peoples is a multicultural society. Each region has a distinct culture that is embraced by the trust from the previous generation ( Tommey and Alligood ,2006). Based on a preliminary study of 20 post partum mothers, there are 17 people did not want to eat chicken dishes, meat and eggs for fear of the seams are not cured and itching . Protein is needed in the process of wound healing episiotomy and in breastfed infants, these conditions need to be an intervention. The purpose of this study was to determine the effect mother class of pregnant women to the knowledge, attitudes and behavior of post partum continence. Method: Research design was pretest and posttest nonequivalent control group with a sample of 40 people, who were divided into 20 groups and 20 controls of the treatment group. Sampling technique by using consecutive. The treatment group got mother class while the control group got health education as usual in health centers. In both groups was measured knowledge, attitudes, and behaviors "post partum continence". Results: The result of this study showed that on paired t test $p=0.000$, that mean at treatment group change on knowledge before and after mother class. On control group showed that not change in knowledge with paired $t$ test $p=0.083$. In indepedent $t$ test $p=0.000$ there is a difference of knowledge between treatment groups and control groups. Paired t test $p=$ 0.000 at the attitude shown that there is a change in attitude before and after treatment. In control group paired t test $p=0.163$ indicates that there is no change in attitude. Independent $t$ test $p=0.000$ shows that there are differences in attitudes between the treatment and control groups . Chi-square test $p=0.000$ on the behavior of incontinence, there are differences in the proportion of incontinence behavior between the treatment and control groups. Discussion:The research recommended mother class intervention for enhance knowledge, attitude and behavior for pregnant women of post partum incontinence culture.
\end{abstract}

Keyword: Mother class, pregnan woman, post partum continence

\begin{abstract}
Masyarakat Indonesia adalah masyarakat yang multikultural. masingmasing daerah memiliki budaya berbeda yang dianut menurut kepercayaan dari generasi sebelumnya. Banyak masyarakat yang percaya dengan budaya generasi sebelumnya karena budaya tersebut diperoleh dari orang tua yang menurut mereka lebih memiliki pengalaman. Dengan kepercayaan ini mereka yakin bahwa perilaku yang ia lakukan akan membawa hasil yang positif dan bermanfaat untuk kesehatan mereka (Tommey and
\end{abstract}

Alligood, 2006). Tidak semua perawatan yang dilakukan dengan berpedoman pada warisan leluhur tersebut bisa diterima sepenuhnya, bisa saja perawatan yang dilakukan tersebut memberikan dampak kesehatan yang kurang menguntungkan bagi ibu dan bayinya (Manurung, 2009). Perilaku atau kebiasaan yang merugikan misalnya: ibu menyusui dilarang makan makanan yang amis misalnya ikan, telor dan lain-lain karena keringat bayinya akan bau tidak sedap. Ibu pasca melahirkan dilarang tidur siang. Ibu post 
partum harus tidur dengan posisi duduk atau setengah duduk karena takut darah kotor naik ke mata (Mubarak dkk, 2012). Berdasarkan hasil penelitian yang dilakukan oleh Yeni Supatemi (2013) 89\% ibu nifas di wilayah kerja Puskesmas Wonotirto Kabupaten Blitar 3tarak"DataLI pantang terhadap jenis makanan tertentu (telor, ikan, ayam). Pernyataan Swasono (1998) yang berpendapat bahwa ada beberapa nilai kepercayaaan masyarakat yang berhubungan dengan perawatan post partum, dengan pengetahuan tentang aspek budaya merupakan hal penting diketahui oleh petugas kesehatan untuk memudahkan dalam melakukan pendekatan untuk memberikan pelayanan kesehatan.

Kelas ibu hamil adalah kelompok belajar ibu-ibu hamil dengan usia kehamilan antara $20 \mathrm{~s} / \mathrm{d} 32$ minggu dengan jumlah peserta maksimal 10 orang, yang melaksanakan kegiatan yang sistematis dalam bentuk tatap muka dalam kelompok yang diikuti diskusi dan tukar pengalaman antara ibu-ibu hamil dan petugas kesehatan guna meningkatkan pengetahuan,merubah sikap dan perilaku ibu agar memahami tentang kehamilan, perubahan tubuh dan keluhan selama hamil, perawatan kehamilan, persalinan, perawatan nifas, KB pasca salin, perawatan bayi baru lahir, mitos / kepercayaan setempat, penyakit menular seksual dan akte kelahiran (Depkes RI, 2009). Berdasarkan studi pendahuluan yang dilakukan tanggal 24 September-06 Oktober 2013 di ruang nifas RS.Ngudi Waluyo Blitar didapatkan 17 dari 20 ibu post partum tidak mau makan masakan ayam, daging dan telor karena takut jahitannya tidak sembuh dan gatal-gatal. Padahal makanan-makanan yang menjadi pantangan tersebut merupakan makanan yang tinggi protein. Protein sangat dibutuhkan dalam proses penyembuhan luka episiotomi maupun pada bayi yang disusui, kondisi tersebut perlu dilakukan sebuah intervensi untuk merekonstruksi budaya pemenuhan nutrisi pada ibu post partum. Berdasarkan keterangan dari tenaga kesehatan setempat klas ibu hamil sudah jarang dilakukan karena keterbatasan tenaga. Intervensi keperawatan pada teori model Medeline Leinenger bagi budaya pasien yang merugikan atau bertentangan dengan konsep hidup sehat adalah merekonstruksi budaya tersebut (Tommey and Alligood, 2006). Berdasarkan uraian tersebut peneliti ingin mengetahui adakah pengaruh pelaksanaan klas ibu hamil terhadap pengetahuan sikap dan perilaku ibu nifas dalam pemenuhan nutrisi di kabupaten Blitar sebagai Upaya Rekronstruksi Budaya "Tarak" (Tidak Makan Makanan Telur, Ayam, Daging Dan Ikan) Pada Ibu Nifas Di Kabupaten Blitar.

Rumusan masalah dalam penelitian ini adalah: adakah pengaruh pelaksanaan kelas ibu hamil terhadap pengetahuan sikap dan perilaku ibu dalam pemenuhan nutrisi ibu nifas Sebagai Upaya Rekronstruksi Budaya "Tarak" pantang terhadap jenis makanan tertentu (telor, ikan, ayam) pada ibu nifas di Kabupaten Blitar.

Tujuan umum dari penelitian ini adalah untuk mengetahui pengaruh kelas ibu terhadap Rekronstruksi Budaya "Tarak" (Tidak Makan Makanan Telur, Ayam, Daging Dan Ikan) Pada Ibu Nifas Di Kabupaten Blitar. Sedangkan tujuan khususnya, yaitu (1) Mengidentifikasi pengetahuan dan sikap Ibu Hamil terhadap budaya "Tarak" sebelum mengikuti kelas ibu hamil, (2) Mengidentifikasi pengetahuan dan sikap Ibu Hamil terhadap budaya "Tarak" setelah diberikan penyuluhan dengan sasaran individu waktu pemeriksaan kehamilan, (3) Mengidentifikasi pengetahuan, sikap dan perilaku "Tarak" ibu nifas setelah mengikuti kelas ibu hamil, (4) Mengidentifikasi pengetahuan, sikap dan perilaku "Tarak" ibu nifas yang diberikan penyuluhan dengan sasaran individu waktu pemeriksaan kehamilan,(5) Membedakan pengetahuan, sikap dan perilaku "Tarak" ibu nifas yang mengikuti kelas ibu hamil dengan ibu hamil yang hanya di beri penyuluhan waktu pemeriksaan kehamilan, (6) Mengidentifikasi adakah pengaruh kelas ibu hamil terhadap pengetahuan, sikap dan perilaku "Tarak"

\section{BAHAN DAN METODE}

Desain dalam penelitian ini adalah pre test and post test nonequivalent control group. Populasi dalam penelitian ini adalah Ibu hamil yang masuk pada trimester 3 di wilayah kerja Puskesmas Wonodadi bulan Maret 2014 sebanyak 60, Sampel sebanyak 40 orang.. Kriteria inklusi dan ekslusi penelitian:Ibu Hamil 34-37 minggu, tidak ada penyakit penyerta, tidak mempunyai alergi telor, ayam, daging dan ikan, ibu hamil yang menganut 
budaya "Tarak". Kriteria Ekslusi meliputi ibu melahirkan sebelum perlakuan selesai, ibu pindah keluar Blitar setelah melahirkan.

Teknik sampling ini menggunakan Consecutive sampling. Variabel dependen Variabel dependen: kelas ibu hamil, variabel independen adalah budaya "tarak".Instrumen yang digunakan dalam penelitian ini adalah kuesioner dan booklet.

Analisa data yang dilakukan dengan Wilcoxon test untuk mengetahui perbedaan pengetahuan dan sikap ibu sebelum dan sesudah mengikuti kelas ibu hamil dan Mann Witheney test untuk membandingkan pengetahuan, sikap dan perilaku antara kelompok yang mengikuti kelas ibu hamil dengan kelompok kontrol.

\section{HASIL PENELITIAN}

\section{Distribusi Karakteristik Responden}

Tabel 1. Distribusi karakteristik responden kelompok perlakuan di kabupaten blitar 14 April - 14 Juni 2014. kelompok perlakuan terbanyak berusia 31-40 th sebanyak 12 responden $(60 \%)$, pendidikan terbanyak pada kelompok perlakuan adalah SMP yaitu 10 responden (50\%), dan pekerjaan yang terbanyak pada kelompok perlakuan adalah IRT yaitu 16 responden $(80 \%)$.

Tabel 2.Distribusi karakteristik responden kelompok kontrol di kabupaten blitar 14 April - 14 Juni 2014.

\begin{tabular}{|c|c|c|c|}
\hline No & Karakteristik & Frekuensi & $\begin{array}{c}\text { Persentase } \\
(\%)\end{array}$ \\
\hline \multirow[t]{4}{*}{1} & Kehamilan Ke & & \\
\hline & -1 & 7 & 35 \\
\hline & -2 & 8 & 40 \\
\hline & -3 & 5 & 25 \\
\hline \multirow[t]{4}{*}{2} & Usia & & \\
\hline & $-\quad<20$ th & 1 & 5 \\
\hline & - $\quad 20-30$ th & 9 & 45 \\
\hline & - $\quad 31-40$ th & 9 & 45 \\
\hline \multirow[t]{2}{*}{3} & $-\quad>40$ th & 1 & 5 \\
\hline & Pendidikan & & \\
\hline \multirow[t]{3}{*}{ \%) } & $-\quad S D$ & 2 & 10 \\
\hline & - SMP & 9 & 45 \\
\hline & - SMA & 9 & 45 \\
\hline \multirow[t]{5}{*}{4} & Pekerjaan & & \\
\hline & - IRT & 15 & 75 \\
\hline & - Swasta & 3 & 15 \\
\hline & - Petani & 1 & 5 \\
\hline & - Lain-lain & 1 & 5 \\
\hline
\end{tabular}

Berdasarkan tabel 2 responden terbanyak pada kelompok kontrol adalah responden dengan kehamilan anak kedua yaitu 8 responden $(40 \%)$, usia responden kelompok kontrol terbanyak berusia 21-30 th dan 31-40 th masing-masing 9 responden (45\%), pendidikan terbanyak pada kelompok kontrol adalah SMP dan SMA masing-masing 9 responden (45\%), dan pekerjaan yang terbanyak pada kelompok kontrol adalah IRT yaitu 15 responden $(75 \%)$.

Pengaruh Pendidikan Kesehatan Terhadap Pengetahuan Ibu

Tabel 3 Pengaruh pendidikan kesehatan terhadap pengetahuan ibu 


\begin{tabular}{|c|c|c|c|c|c|c|}
\hline & Pre test & PostTest & Pre Test & Posttest & Perlakuan & Kontrol \\
\hline $\mathrm{N}$ & 20 & 20 & 20 & 20 & 20 & 20 \\
\hline SD & 2,555 & 2,43 & 1,943 & 1,789 & 2,43 & 1,789 \\
\hline Mean & 15 & 20,7 & 16,25 & 16,4 & 20,7 & 16,4 \\
\hline & \multicolumn{2}{|c|}{ Paired T Test $\mathrm{p}=0,000$} & \multicolumn{2}{|c|}{$\begin{array}{c}\text { Paired T Test } \\
\mathrm{p}=0,083\end{array}$} & \multicolumn{2}{|c|}{ Independent $T$ Test $\mathrm{p}=0,000$} \\
\hline
\end{tabular}

Berdasarkan tabel 3 pada kelompok perlakuan didapatkan hasil pada uji paired t test $\mathrm{p}=0,000$ menunjukkan bahwa ada perubahan pengetahuan antara sebelum dan sesudah diberikan pendidikan kesehatan. Pada kelompok kontol didapatkan hasil uji paired t test $\mathrm{p}=0,083$ menunjukkan bahwa tidak terjadi perubahan pengetahuan pada kelompok kontrol. Pada uji indenpedent $\mathrm{t}$ test $\mathrm{p}=0,000$ menunjukkan bahwa ada perbedaan pengetahuan antara kelompok perlakuan dan kelompok kontrol.

Pengaruh Pendidikan Kesehatan Terhadap Sikap Ibu

Tabel 4 Pengaruh pendidikan kesehatan terhadap sikap ibu

\begin{tabular}{ccccccc}
\hline & \multicolumn{2}{c}{ Perlakuan } & \multicolumn{2}{c}{ Kontrol } & \multicolumn{2}{c}{ Nilai post } \\
\cline { 2 - 7 } & Pre test & Post Test & PreTest & Posttest & Perlakuan & Kontrol \\
\hline N & 20 & 20 & 20 & 20 & 20 & 20 \\
SD & 3,045 & 2,94 & 4,404 & 4,407 & 2,94 & 4,407 \\
Mean & 45,7 & 53,3 & 47,35 & 47,45 & 53,3 & 47,35 \\
\hline \multicolumn{4}{c}{ Paired T Test $\mathrm{p}=0,000$} & \multicolumn{2}{c}{ Paired T Test } & Independent T Test $\mathrm{p}=0,000$ \\
& & \multicolumn{2}{c}{$\mathrm{p}=0,163$} &
\end{tabular}

Berdasarkan tabel 4 pada kelompok perlakuan didapatkan hasil pada uji paired t test $\mathrm{p}=0,000$ menunjukkan bahwa ada perubahan sikap antara sebelum dan sesudah diberikan pendidikan kesehatan. Pada kelompok kontol didapatkan hasil uji paired t test $\mathrm{p}=0,163$ menunjukkan bahwa tidak terjadi perubahan sikap pada kelompok kontrol. Pada uji independent $\mathrm{t}$ test $\mathrm{p}=0,000$ menunjukkan bahwa ada perbedaan sikap antara kelompok perlakuan dan kelompok kontrol.

\section{Perilaku Tarak Ibu}

Tabel 5 Perilaku tarak ibu

\begin{tabular}{lcccc}
\hline \multirow{2}{*}{ Kelompok } & \multicolumn{2}{c}{ Pantangan } & \multirow{2}{*}{ Total } & p \\
\cline { 2 - 3 } & Ya & Tidak & \multirow{2}{*}{$\mathrm{p}=0,000$} \\
\hline Perlakuan & 2 & 18 & 20 & \\
\hline Control & 13 & 7 & 20 & \\
\hline Total & 15 & 25 & 40 & \\
\hline
\end{tabular}

Berdasarkan tabel 5 didapatkan hasil pada uji Chi-square $\mathrm{p}=0,000$ menunjukkan bahwa ada perbedaan proporsi perilaku tarak antara kelompok perlakuan dan kelompok kontrol.

PEMBAHASAN

\section{Pengetahuan Ibu Terhadap Budaya "Tarak"}

Hasil penelitian tingkat pengetahuan ibu yang mengikuti klas ibu hamil tentang gizi ibu nifas yang di gambarkan pada tabel 3 tampak terjadi peningkatan pengetahuan ibu nifas yang mengikuti klas ibu hamil pada saat kehamilannya. Berdasarkan hasil uji statistic menggunakan paired $T$ test didapatkan nilai $\mathrm{p}=0,00$. Karena nilai $\mathrm{p}<0,05$ artinya ada perubahan tingkat pengetahuan responden setelah mengikuti klas ibu hamil. Peningkatan pengetahuan responden yang mengikuti klas ibu hamil tersebut telah sesuai dengan harapan dari program pemerintah tentang klas ibu hamil yaitu meningkatkan pengetahuan ibu agar memahami tentang kehamilan, perubahan tubuh dan keluhan selama hamil,perawatan kehamilan, persalinan, perawatan nifas, KB pasca salin, perawatan bayi baru lahir, mitos / kepercayaan setempat, penyakit menular seksual dan akte kelahiran (Depkes RI, 2009). Menurut Setiawati (2008) dalam Abdul.F (2012) pendidikan kesehatan merupakan serangkaian upaya yang ditujukan untuk menggugah kesadaran, memberikan dan meningkatkan pengetahuan sasaran 
pendidikan kesehatan yang menyangkut tentang pemeliharaan kesehatan serta peningkatan kesehatan baik untuk individu, keluarga, kelompok maupun masyarakat. Dalam penelitian ini pelaksanaan klas ibu hamil dilaksanakan sebanyak 2 kali dengan materi yang terstuktur, untuk pertemuan pertama materi yang di berikan adalah hubungan protein dengan penyembuhan luka yang kemudian dilanjutkan dengan pertemuan ke 2 dengan materi pentingnya gizi ibu nifas bagi dirinya dan bayi yang disusuinya. Metode tersebut dikatakan sangat efektif dapat dibuktikan dengan nilai rata-rata pretest yang dilakukan pada saat ibu belum mengikuti klas ibu hamil adalah 15 yang artinya rata-rata responden dapat menjawab pertanyaan tentang gizi ibu nifas $60 \%$ dari 25 item pertanyaan, sedangkan nilai rata-rata posttest yang dilakukan pada saat ibu menjalani masa nifas adalah 21 yang artinya rata-rata responden dapat menjawab pertanyaan $84 \%$ dari 25 item pertanyaan, sehingga dapat disimpulkan bahwa sebelum mengikuti klas ibu hamil sebenarnya responden telah memiliki pengetahuan yang baik dan setelah mengikuti klas ibu hamil dan menjalani masa nifasnya responden memiliki pengetahuan yang sangat baik.

Hasil penelitian tingkat pengetahuan ibu yang tidak mengikuti klas ibu hamil (hanya diberikan penyuluhan oleh bidan saat melakukan pemeriksaan kehamilan) tentang gizi ibu nifas tidak mengalami peningkatan. Nilai rata-rata pretest sebelum mendapatkan penyuluhan dari bidan adalah 16 yang artinya rata-rata responden dapat menjawab pertanyaan tentang gizi ibu nifas $64 \%$ dari 25 item pertanyaan, setelah dilakukan post test pada saat ibu menjalani masa nifas pengetahuan responden tersebut tidak mengalami peningkatan. Dapat disimpulkan pengetahuan sebelum dan setelan mendapatkan penyuluhan dari bidan tetap baik. Berdasarkan hasil uji statistic menggunakan paired $T$ test didapatkan nilai $\mathrm{P}=0,83$. Karena nilai $\mathrm{P}<0,05$ artinya tidak ada perubahan tingkat pengetahuan responden setelah diberikan penyuluhan oleh bidan tentang gizi ibu nifas. Sedangkan rata-rata nilai pengetahuan pada kelompok yang mengikuti klas ibu hamil adalah 21 sedangkan pengetahuan ibu yang tidak mengikuti klas ibu hamil adalah 16. Pengetahuan seseorang menurut Notoadmodjo (2010) dapat dipengaruhi oleh beberapa factor eksternal yaitu, pendidikan, informasi dan pengalaman. Tehnik dan media dalam menyampaikan sebuah informasi akan memberikan pengaruh pada pengetahuan seseorang (Anwar, 2007). Dalam penelitian ini kelompok kontrol hanya di berikan penyuluhan tentang gizi ibu nifas oleh bidan sebanyak satu kali saat melakukan pemeriksaan kehamilan dengan media yang digunakan adalah leaflead. Sedangkan kelompok perlakuan telah mengikuti klas ibu hamil dan di berikan materi penyuluhan tentang hubungan protein dengan penyembuhan luka serta pentingnya gizi ibu nifas bagi dirinya dan bayi yang disusuinya, materi tersebut di berikan secara terstuktur, hal ini sesuai dengan Depkes RI (2009) pembahasan materi menjadi efektif karena pola penyajian materi terstruktur dengan baik. Media yang digunakan dalam penyampaian materi pada klas ibu hamil adalah LCD dan booklet. Perbedaan tehnik dan media yang digunakan dalam pemberian informasi tersebut yang membedakan peningkatan pengetahuan kelompok perlakuaan dan kelompok kontrol.

Menurut Notoatmodjo (2010) bahwa semakin tinggi pendidikan seseorang maka akan semakin mudah menerima atau menyesuaikan dengan hal yang baru. Karena pendidikan mempengaruhi proses belajar sehingga dengan memiliki pengetahuan yang lebih tinggi akan cenderung memperoleh lebih banyak informasi baik dari orang lain maupun dari media masa. Semakin banyak informasi yang didapatkan maka semakin banyak pula pengetahuan yang didapatkan tentang kesehatan. Pendidikan bukan hanya bisa didapat dari pendidikan formal tetapi juga nonformal. Berdasarkan hasil penelitian didapatkan $50 \%$ (10) responden dari kelompok yang mengikuti klas ibu hamil pernah mendapatkan informasi tentang Gizi ibu nifas sebelumnya, hal ini dapat dikatakan bahwa ke 10 responden tersebut telah mengikuti pendidikan non formal. Dari 10 responden tersebut 8 responden mendapat informasi dari tenaga kesehatan sedangkan sisanya (2 responden) mendapat informasi dari media cetak. Selain itu salah satu factor yang dapat mempengaruhi pengetahuan seseorang adalah pengalaman, menurut Notoatmojo (2010) pengalaman merupakan 
suatu cara untuk mendapatkan kebenaran dari pengetahuan. Dari hasil penelitian ini didapatkan 90\% (18 responden) adalah ibu yang telah mempunyai anak lebih dari satu, maka dari itu pengalaman ibu menjadi ibu nifas sebelumnya dapat menambah pengetahuan ibu dalam memenuhi kebutuhan gizi ibu selama nifas.

\section{Sikap Ibu Terhadap Budaya "Tarak"}

Hasil penelitian tentang sikap ibu yang mengikuti klas ibu hamil tentang gizi ibu nifas yang di gambarkan pada tabel 4 memperlihatkan terjadi peningkatan sikap ibu nifas yang mengikuti klas ibu hamil pada saat kehamilannya. Berdasarkan hasil uji statistic menggunakan paired $T$ test didapatkan nilai $\mathrm{p}=0,00$. Karena nilai $\mathrm{p}<0,05$ artinya ada perubahan sikap responden setelah mengikuti klas ibu hamil. Dari hasil pre didapatkan nilai rata-rata sikap baik dan post test mempunyai nilai rata-rata sikap sangat baik hal ini terlihat dari peningkatan nilai yaitu dari 45 menjadi 53. Berdasarkan pretest di dapatkan rata-rata nilai pengetahuan yang baik dengan nilai sikap yang baik pula, sedangkan posttest didapatkan rata-rata nilai pengetahuan yang sangat baik dan diikuti nilai sikap yang sangat baik pula. Menurut Notoatmodjo (2010) pengetahuan, pikiran, keyakinan dan emosi memegang peran penting dalam menentukan sikap yang utuh. Sikap ibu yang mengikuti klas ibu hamil pada posttest didasari oleh pengetahuan responden yang baik pula, hal ini karena responden mengangap klas ibu hamil yang mereka ikuti sangat bermanfaat bagi ibu karena pelaksanaan klas ibu hamil tidak membosankan, pada saat kegiatan ibu bertukar pengalaman satu dengan yang lain hal ini karena ibu hamil yang mengikuti sangat heterogen, ada yang kehamilan pertama, kedua bahkan ada yang kehamilannya sudah ke lima kalinya. Selain itu komunikasi yang sangat interaktif pemberi materi saat pembelajaran membuat ibu antusias dalam mengikuti pembelajaran tersebut. Hal ini sesuai dengan teoti Anwar (2010) komunikasi kesehatan dengan menggunakan prinsip desain pengajaran adalah salah satu upaya untuk menumbuhkan sikap. Dengan komunikasi yang dilakukan pemateri dengan ibu maupun ibu satu dengan yang lainnya dalam klas ibu hamil selama 2 kali pertemuan dapat meningkatkan kepercayaan maupun keyakinan bagi ibu bahwa apa yang disampaikan baik bagi kesehatan ibu maupun bayinya, dan dapat membentuk niat ibu untuk menghidari "tarak"

Sedangkan sikap ibu yang tidak mengikuti klas ibu hamil berdasarkan hasil uji statistic menggunakan paired $T$ test didapatkan nilai $\mathrm{p}=0,163$. Karena nilai $\mathrm{p}<0,05$ artinya tidak ada perubahan sikap responden setelah diberi pendidikan kesehatan tentang Gizi ibu nifas oleh bidan Dapat disimpulkan bahwa nilai sikap ibu yang tidak mengikuti klas ibu hamil dipengaruhi oleh pengetahuan, hal ini dapat dilihat dari hasil pre dan post test pada kelompok ini tidak ada peningkatan nilai pengetahuan. Namun menurut Notoatmodjo (2010) tiga hal yang dapat membentuk sikap antara lain kepercayaan, ide dan konsep terhadap suatu objek, kehidupan emosional atau emosional suatu objek dan kecenderungan untuk bertindak (trend to behave). Sehingga sikap ibu yang tidak mengikuti klas ibu hamil bisa juga terbentuk dari kepercayaan yang telah lama ada pada dirinya dan didukung oleh lingkungan disekitarnya.

\section{Perilaku "Tarak" Ibu Nifas}

Hasil penelitian tentang perilaku "tarak" ibu nifas digambarkan pada tabel 5 berdasarkan hasil uji statistic menggunakan Chi-square didapatkan $\mathrm{p}=0,000$ yang artinya terdapat perbedaan antara perilaku "tarak" pada ibu nifas yang mengikuti klas ibu hamil dengan ibu yang hanya mendapatkan pendidikan kesehatan tentang gizi ibu menyusui. Salah satu tujuan dari klas ibu hamil menurut Depkes RI (2009) adalah mengubah mitos/kepercayaan/adat istiadat setempat yang berkaitan dengan kesehatan ibu dan anak. Sedangkan menurut teori Leininger (1978) dalam Sudiharto (2007) keperawatan transkultural adalah suatu ilmu yang humanis dan difokuskan pada perilaku individu atau kelompok, serta proses mempertahankan atau meningkatkan perilaku sehat atau sakit secara fisik dan psikokultural sesuai latar belakang. Berdasarkan teori Transkultural asuhan keperawatan ditujukan memandirikan individu sesuai dengan budaya klien dengan strategi yang digunakan dalam asuhan keperawatan adalah perlindungan, negosiasi, atau rekonstrusi (mengubah) budaya klien. Nilai-nilai budaya adalah sesuatu yang 
dirumuskan dan ditetapkan oleh penganut budaya yang dianggap baik atau buruk dan rekonstruksi budaya dilakukan bila budaya tersebut merugikan status klien (Alligood, 2006). Sehingga klas ibu hamil ini merupakan aplikasi dari keperawatan traskultural yang dilakukan oleh peneliti. Karena peneliti menganggap budaya "tarak" khususnya tidak makan makanan telur, ayam, daging dan ikan dinilai akan merugikan ibu nifas yaitu luka yang tak kunjung sembuh atau pun gizi bayi yang kurang baik. Berdasarkan hasil penelitian didapatkan $70 \%$ dari 20 ibu sebelum mengikuti klas ibu hamil dan 50\% dari 20 ibu sebelum mendapatkan pendidikan kesehatan yang dari bidan mengatakan bahwa ibu nifas tidak boleh makan ikan, ayam maupun telur karena mereka menganggap hal tersebut dapat membuat kemaluan gatal-gatal dan luka bekas jahitan tidak sembuh. Namun dari 20 ibu yang mengikuti klas ibu hamil hanya $10 \%$ yang masih bertahan pada budaya tersebut ketika nifas. Sedangkan 20 ibu yang mendapatkan pendidikan kesehatan dari bidan tetap 50\% bertahan dengan budaya tersebut saat masa nifas. Hal ini terbukti bahwa klas ibu hamil dapat merekonstruksi budaya "tarak".

Menurut Waqid iqbal.M (2012) pengetahuan adalah salah satu unsur dari sosial budaya dan pengetahuan juga memiliki pengaruh yang sangat besar terhadap kesehatan. Berdasarkan penelitian ini didapatkan adanya peningkatan pengetahuan tentang gizi ibu nifas pada ibu yang mengikuti klas ibu hamil dan diikuti oleh adanya perilaku "tarak" yang lebih sedikit pada ibu nifas yang mengikuti klas ibu hamil dibandingkan dengan yang hanya mendapat pendidikan kesehatan dari bidan. Hal ini didukung oleh teori tersebut diatas bahwa salah satu unsur pada budaya adalah pengetahuan. Selain pengetahuan unsur lain yang terkait dengan sosial budaya antara lain kepercayaan, kesenian, moral, hukum, adat istiadat dan kemampuan serta kebiasaan yang telah dilakukan oleh masyarakat (Waqid iqbal.M, 2012). 10\% ibu yang berperilaku "tarak" walaupun telah mengikuti klas ibu selama hamil, mungkin karena mereka masih terbelenggu dengan tradisi dan nasehat dari orang tua maupun orang lain. Walaupun ibu memiliki pengetahuan yang baik sedangkan tradisi "tarak" masih dianut oleh masyarakat sekitar budaya tersebut akan tetap sulit untuk di ubah. Hal ini sesuai dengan teori Waqid iqbal.M (2012) bahwa adat istiadat dan pelaku masyarakat sering kali menjadi penghalang terciptanya hidup sehat di masyarakat.

\section{SIMPULAN DAN SARAN Simpulan}

Hasil penelitian tentang pengetahuan pada kelompok perlakuan didapatkan hasil pada uji Paired T Test $\mathrm{p}=0,000$ menunjukkan bahwa ada perubahan pengetahuan antara sebelum dan sesudah diberikan pendidikan kesehatan. Pada kelompok kontrol didapatkan hasil uji Paired T Test $\mathrm{p}=0,083$ menunjukkan bahwa tidak terjadi perubahan pengetahuan pada kelompok kontrol. Pada uji Indepedent $T$ Test $\mathrm{p}=0,000$ menunjukkan bahwa ada perbedaan pengetahuan antara kelompok perlakuan dan kelompok kontrol. Pada pengukuran sikap didapatkan hasil pada uji Paired T Test $\mathrm{p}=0,000$ menunjukkan bahwa ada perubahan sikap antara sebelum dan sesudah diberikan pendidikan kesehatan. Pada kelompok kontol didapatkan hasil uji Paired $T$ Test $\mathrm{p}=0,163$ menunjukkan bahwa tidak terjadi perubahan sikap pada kelompok kontrol. Pada uji Independent T Test $\mathrm{p}=0,000$ menunjukkan bahwa ada perbedaan sikap antara kelompok perlakuan dan kelompok control. Pada pengukuran perilaku tarak hasil pada uji Chi-square $\mathrm{p}=0,000$ menunjukkan bahwa ada perbedaan proporsi perilaku tarak antara kelompok perlakuan dan kelompok kontrol.

\section{Saran}

Untuk lahan agar perawat dapat mensosialisasikan tentang nutrisi ibu nifas pada kelas ibu hamil.

\section{DAFTAR RUJUKAN}

Depkes RI. 2009.Pedoman Pelaksanaan Kelas Ibu Hamil. Jakarta. Dirjend Bina Kesehatan Masyarakat

Manurung, Yunani Dewi. 2009. perawatan Post Partum Menurut Perspektif Budaya Jawa. Sumatera Utara. Universitas Sumatera Utara (skripsi)

Mubarak, dkk. 2012. Pengantar dan Teori Ilmu Sosial Budaya Dasar Kebidanan. Jakarta: EGC 
Notoatmodjo, Soekidjo. 2010.Promosi kesehatan teori dan aplikasi. Jakarta: Rineka Cipta

Nursalam. 2008. Konsep dan Penerapan Metodologi penelitian Ilmu Keperawatan. Jakarta: Salemba Medika

Saifudin dan Yusuf. 2010. Nikmatnya seks islami. Hal. 116. Yogyakarta: pustaka Marwa (Anggota IKAPI). (ebook online)

Saleha, sitti. 2009. Asuhan Kebidanan pada Masa Nifas. Jakarta: Salemba Medika Suherni, dkk. 2009. Perawatan Masa Nifas. Yogyakarta: Fitramaya

Supatemi Yeni (2013). Struktur budaya dan sosial ibu post partum berdasarkan pendekatan teori keperawatan transkultural medeleine leininger di kecamatan wonotirto. Stikes Patria Husada Blitar. (Skripsi)

Syaifudin A, dkk. (2006). Buku Acuan Nasional Pelayanan Kesehatan Maternal dan Neonatal. Jakarta: YBPSP

Tommey and Alligood. (2006). Nursing Theorist and Their Work. Philadelphia USA: Mosby.

Wong,D.L, Hockenberry M, Wilson,D, Winkelstein,M.L, \& Schwartz, P.(2002). Buku Ajar Keperawatan Pediatrik Wong, Ed 6, Vol I.Alih Bahasa Agus Sutarna. Jakarta:EGC 